\begin{tabular}{l|l|l} 
Jurnal Eksplorasi Akuntansi & $\begin{array}{l}\text { Vol. 2, No 1, Seri A, Februari 2020, Hal 1984-2000 } \\
\text { ISSN : 2656-3649 (Online) } \\
\text { http://jea.ppj.unp.ac.id/index.php/jea/issue/view/17 }\end{array}$
\end{tabular}

\title{
PENGARUH PENDAPATAN ASLI DAERAH TERHADAP BELANJA DAERAH DAN BUDGET RATCHETING SEBAGAI VARIABEL MODERASI
}

\section{(Studi Pada Pemerintah Daerah Kabupaten Dan Kota Di Provinsi Sumatera Barat Tahun 2013 - 2017)}

\author{
Aldy Andrean ${ }^{1}$, Vita Fitria Sari² \\ ${ }^{1}$ Alumni Jurusan Akuntansi Fakultas Ekonomi Universitas Negeri Padang \\ ${ }^{2}$ Jurusan Akuntansi Fakultas Ekonomi Universitas Negeri Padang \\ *Korespondensi: aldyandrean18@gmail.com
}

\begin{abstract}
The variables tested in this study consisted of Regional Original Income as an independent variable measured by the number of several revenue items in the Realized Budget and Regional Expenditure Report as the dependent variable measured by looking at expenditure items in the Realized Budget Report, then Budget Ratcheting as a moderating variable as measured by the Aranda model (2010). The sample in this study was conducted in 19 Regencies / Cities of West Sumatra Province in 2013 - 2017. The results of the study showed that the Local Revenue significantly affected Regional Expenditure and Budget Ratcheting as a moderating variable strengthening the relationship between Own Revenue and Regional Expenditure.
\end{abstract}

Keywords: Regional Expenditure, Budget Ratcheting, Budget Realization Report, Local Revenue

How to cite (APA $6^{\text {th }}$ style):

Andrean, A. \& Sari, V. F. (2020). Pengaruh Pendapatan Asli Daerah terhadap Belanja Daerah dan Budget Ratcheting sebagai Variabel Moderasi (Studi pada Pemerintah Daerah Kabupaten dan Kota di Provinsi Sumatera Barat Tahun 2013-2017). Jurnal Eksplorasi Akuntansi, 2(1), Seri A, 1984-2000.

\section{PENDAHULUAN}

Sistem pemerintahan di Indonesia menjadi desentralisasi ditandai dengan disahkannya dan beberapa kali terjadi revisi hingga terakhir yakni UU No. 23 tahun 2014 tentang Pemerintahan Daerah. Undang - undang tersebut menjelaskan segala urusan pemerintahan daerah serta Dewan Perwakilan Rakyat Daerah dilakukan berdasarkan asas otonomi dan tugas keikutsertaan dengan prinsip otonomi seluas - luasnya dalam sistem dan prinsip Negara Kesatuan Republik Indonesia. Dalam kegiatanya pemerintah daerah memiliki anggaran pendapatan dan belanja daerah, dimana meliputi instrumen akuntabilitas aktivitas pengelolaan dana publik dan pelaksanaan program program dengan pendanaan dari publik. Program-program yang telah direncanakan tersebut diawali dengan penyusunan dan pengalokasian dana dalam skala waktu satu tahun yang disebut penganggaran. (Halim dan Kusufi, 2012:23). 
Penyusunan anggaran pemerintah daerah merupakan suatu proses politik, terjadinya konsepsi tahapan yang rumit dan memberikan nuansa politik yang tinggi, sehingga mengakibatkan penganggaran masih bersifat tertutup dan hanya melibatkan segelintir politisi dan birokrasi. Forester, (1991) dalam Abdullah dan Nazry, (2014) bahwa anggaran besar kemungkinan keputusan yang diambil dipengaruhi oleh beberapa faktor seperti politik, ekonomi, teknologi, namun dampak dari faktor - faktor tersebut tidak bisa diketahui sampai dengan anggaran terealisasi. Pemerintahan daerah dituntut untuk dapat mandiri dalam mengelola pendanaan, akan terlihat bagaimana strategi dalam realisasi program yang telah direncanakan, tersediannya sarana dan prasarana publik dan pelayanan kepada masyarakat.

PP No. 71 Tahun 2010 menjelaskan belanja daerah adalah pengeluaran dari Rekening Kas Umum Negara/Daerah yang bersifat mengurangi saldo anggaran lebih dalam periode tahun anggaran yang bersangkutan dimana tidak akan diperoleh pembayarannya kembali oleh pemerintah. Pemerintah daerah dalam mengalokasikan belanja daerah dituntut untuk dapat meningkatkan dalam kualitas pelayanan publik, dan dialokasikan untuk hal produktif lainnya guna meningkatan taraf kehidupan masyarakat didaerah tersebut. UU No 33 Tahun 2004 menyatakan pendapatan asli daerah, selanjutnya disebut PAD merupakan pendapatan yang diperoleh daerah berdasarkan peraturan daerah dalam prakteknya diperoleh dengan cara di dimintai sesuai dengan peraturan perundang - undangan. Pendapatan asli daerah terdiri dari hasil pajak daerah, hasil retribusi daerah, hasil pengelolaan kekayaan daerah yang dipisahkan, dan lain - lain PAD yang sah. Pada saat ini masih banyak masalah yang dihadapi pemerintah daerah terkait dengan upaya meningkatkan kualitas pemerintahan daerah, dengan keterbatasan sarana dan prasarana yang tidak mendukung untuk investasi menimbulkan pertanyaan bagaimana sebenarnya PAD terhadap belanja daerah, apakah karena PAD yang rendah alokasi dan kurang tepat.

Tahap awal pengganggaran sudah terjadi beberapa permasalahan. Isaken (2005) mengatakan dalam penelitiannya meskipun tahap perencanaan anggaran tidak berkaitan langsung dengan uang yang nyata tapi penyusunan anggaran dapat menjadi bagian dari korupsi, yang memanifestasikan korupsi tersebut dalam pembayaran aktual atau transfer uang pada tahap eksekusi (realisasi). Masalah lain akan terjadi ketika penyusunan anggaran tersebut muncul kecendrungan penyusun untuk mengambil keputusan menggunakan kinerja saat ini sebagai kriteria dalam menentukan target dimasa depan, dimana hal tersebut disebut dengan ratchet (Weitzman, 1980). Ratchet tersebut akan memperlihatkan terjadi teori agensi pada pelaksanaanya, teori agensi menjelaskan terjadinya kesepakatan antara dua pihak, yaitu pihak yang memberikan wewenang disebut principal dan pihak yang menerima wewenang disebut dengan agent (Halim dan Abdullah, 2006). Agency problem terjadi ketika principal mendelegasikan kewenangan untuk mengambil keputusan kepada agent. Hubungan tersebut akan menimbulkan permasalahan yaitu adanya asimetri informasi, dimana pihak pemerintah sebagai principal memiliki informasi yang lebih daripada pihak agent (masyarakat). Keunggulan informasi tersebut bersumber dari fakta bahwa eksekutif adalah pelaksana semua fungsi pemerintah daerah, sehingga anggaran untuk pelaksanaan pelayanan publik memiliki kecendrungan mengusulkan anggaran belanja yang lebih besar (asas maksimal), dan untuk anggaran pendapatan eksekutif cenderung mengusulkan target pendapatan yang lebih kecil (asas minimal), agar ketika realisasi target tersebut lebih mudah dicapai (Halim dan Abdullah, 2006).

Budget ratcheting akan terlihat saat tindakan eksekutif menyusunan anggaran, dasar atas keputusan yang diambil menggunakan informasi saat ini sebagai kriteria dalam mencapai target anggaran tahun berikutnya. Halim \& Abdullah (2006) mengatakan dalam penelitiannya bahwa usulan anggaran yang mengandung slack seperti ini merupakan gambaran adanya asimetri 
informasi antara eksekutif dan legislatif. Penelitian mengenai budget ratcheting dalam penganggaran organisasi sektor publik telah dilakukan dalam berbagai konteks. Lee dan Plummer (2007) menjelaskan adanya efek ratchet dalam anggaran sekolah di Texas, dalam penelitiannya mengatakan bahwa organisasi pemerintahan cenderung melakukan produksi berlebihan pada barang dan jasa pubik, effort reduction dan menggunakan anggaran untuk aktivitas yang tidak penting menjelang akhir tahun periode. Lee dan Plummer (2007) penelitian yang dilakukan memberikan hasil varian anggaran (selisih anggaran dengan realisasi) memiliki hubungan positif saat tahun sekarang dengan tahun masa lalu. Perilaku pemeritah daerah dalam menanggapi kenaikan atas anggaran pendapatan periode saat ini yang cenderung responsif, berbeda dengan penurunan pendapatan pada periode di masa depan sebagai pengaruh negatif terhadap perubahan anggaran periode tahun berjalan, hal ini diketahui sebagai budget ratcheting. Hal ini berarti saat kekurangan pendapatan saat tahun berjalan tidak terkait dengan tinggi atau rendahnya pendapatan di masa mendatang (Lim, 2011).

Nurhayati (2018) menyatakan bahwa budget racheting pada dasarnya merupakan upaya pemerintah daerah dalam memperbaiki dan merevisi pencapaian target guna memperoleh gambaran kinerja di masa lalu. Budget ratcheting juga merupakan sebuah kecendrungan dalam pembuatan perencanaan guna menentukan tujuan dimasa depan dengan menggunakan kinerja saat ini. Abdullah \& Junita (2016) dalam penelitannya menemukan bahwa budget ratcheting menjadi variabel moderasi dalam hubungan pendapatan asli daerah dengan belanja daerah, dan ketika penyusunan anggaran dilakukan disertai dengan masalah keagenan yang disusun oleh pengusul anggaran dan pemberi persetujuan yang memiliki kepentingan masing - masing.

Penelitian mengenai budget ratcheting dalam sektor pemerintahan penting dilakukan dikarenakan beberapa hal. Pertama, budget ratcheting pada proses penyusunan anggaran pemerintah daerah cenderung mengandung adanya perilaku bias penyusunan anggaran yang dapat mempengaruhi anggaran tersebut dari tahun sebelumnya ke tahun depan. Marlowe (2009) menyatakan pertumbuhan anggaran pemerintah secara umum mengacu pada norma klasik, dimana realisasi anggaran tahun sebelumnya ditambah tingkat pertumbuhan tertentu. Sehingga akibat dari kondisi tersebut pertumbuhan dari anggaran yang tidak efisien dan merugikan kepentingan publik. Kedua, budget ratcheting akan memperlihatkan bahwa anggaran pada periode selanjutnya mengandung incrementalism yang tidak selaras dengan tujuan penerapan anggaran berbasis kinerja dalam upaya meningkatkan akurasi tahapan perencanaan dan memperkuat aspek akuntabilitas kinerja dalam siklus penganggaran.

Pemerintah Provinsi Sumatera Barat merupakan salah satu pemerintah daerah di Indonesia yang memiliki catatan prestasi yang cukup baik. Anggaran Pendapatan dan Belanja Daerah (APBD) Pemprov Sumatera Barat meningkat dari tahun ke tahun. Pada sisi pendapatan daerah mengalami peningkatan rata - rata sebesar $16 \%$ per tahun selama kurun waktu 2013 - 2017 dan 6\% per tahun di sisi Pendapatan Asli Daerah (PAD). Pendapatan Asli Daerah pada Provinsi Sumatera Barat mengalami peningkatan yang semula sebesar Rp. 1,3 triliun pada tahun 2013 menjadi Rp. 2 triliun pada tahun 2017. Aspek realisasi dari PAD menunjukkan angka 3-6\% selama kurun waktu periode anggaran untuk melampui target anggaran yang direncanakan. Perkembangan yang terjadi pada komponen pendapatan di APBD pemerintah provinsi Sumatera Barat mengindikasikan bahwa anggaran pemerintah di sisi pendapatan cenderung underforecast.

Belanja daerah Pemprov Sumatera Barat mengalami pertumbuhan rata - rata $10 \%$ per tahun selama kurun waktu 2013 - 2017. Belanja Daerah yang pada tahun 2013 sebesar Rp. 2,8 triliun meningkat menjadi Rp. 4,4 triliun di tahun 2017. Namun, realisasi belanja daerah cenderung fluktuatif di angka $89-93 \%$ dari anggaran yang telah disusun. Situasi ini mengindikasikan bahwa 
capaian realisasi anggaran memerlukan peningkatan dari sisi perencanaan dan pelaksanaan anggaran. Ruang lingkup pada APBD Pemprov Sumatera Barat ini yang memotivasi peneliti untuk melakukan penelitian apakah Pendapatan Asli Daerah berpengaruh terhadap belanja daerah dan budget ratcheting mempengaruhi hubungan tersebut.

\section{REVIU LITERATUR DAN HIPOTESIS Teori Keagenan}

Jensen dan Meckling (1976) menjelaskan bahwa hubungan keagenan merupakan kontrak antara pihak principal dan agent, pihak principal memperkerjakan pihak agent untuk memberikan suatu jasa dan kemudian mendelegasikan wewenang pengambilan keputusan kepada agent tersebut. Teori ini berprinsip bahwa adanya hubungan kerja antara pihak yang memberi wewenang (principal) dengan pihak yang menerima wewenang (agent), dalam bentuk kontrak kerjasama, dimana implikasi dari teori ini dapat menimbulkan perilaku efisiensi ataukan perilaku opurtunistik bagi pihak agent. Dalam sektor publik hubungan keagenan terjadi antara pihak eksekutif (agent) dan legislatif (principal). Dalam konteks penyusunan anggaran, usulan yang diajukan eksekutif memiliki muatan yang mengutamakan kepentingan eksekutif, dimana eksekutif. Pada akhirnya keunggulan informasi yang dimiliki oleh eksekutif yang dipergunakan untuk menyusun anggaran akan berhadapan dengan keunggulan kekuasaan yang dimiliki oleh legislatif.

Masalah keagenan pada sektor publik tidak hanya terjadi pada pihak eksekutif dan legislatif, namun juga antara legislatif dan masyarakat. Dimana pihak legislatif adalah agent dan publik (masyarakat) adalah principal (Fozzard, 2001). Dalam konteks pembuatan kebijakan, masyarakat sebagai principal mengharapkan keputusan-keputusan yang mengatasnamakan kepentingan masyarakat secara umum, begitupun saat pengalokasian belanja pada anggaran, maka keputusan yang diharapkan mewakili kepentingan atas pihak principal (masyarakat). Namun, kedudukan legislatif sebagai agent akan menunjukkan terjadi tindakan self interest, saat memaksimalkan utilitasnya dalam pembuatan keputusan yang terkait dengan publik. Persoalan ini semakin menjadi nyata ketika masyarakat tidak memiliki saran atau intitusi formal untuk mengawasi kinerja legislatif, sehingga perilaku moral hazard legislatif dapat terjadi dengan mudah.

\section{Pendapatan Asli Daerah}

Undang-Undang No. 33 tahun 2004 menyatakan pendapatan asli daerah adalah pendapatan yang diperoleh daerah dari pungutan atas peraturan daerah masing - masing yang dilandasi dengan perundang - undangan. Sehingga dapat juga dikatakan bahwa PAD merupakan semua penerimaan daerah yang berasal dari sumber ekonomi asli daerah tersebut. Pendapatan asli daerah diakui saat adanya pemerintah daerah menerima pajak diantaranya pajak properti, pajak pendapatan, dan pajak penjulan, dendan dan lisensi, transfer antar pmerintah dan pendapatan lain - lain. Lim (2011) dalam penelitiannya mengatakan pemerintah daerah memiliki pendapatan yang diklasifikasikan atas sumber dana dan kategori kegiatan mencakup segala pendapatan yang disediakan untuk memodali kegiatan pemerintah tersebut.

Potensi suatu pemerintah daerah akan menjadi sumber pendapatan daerah itu sendiri, dasar atas pengutan tersebut dari peraturan perundang - undangan yang berlaku. Peraturan daerah yang diterbitkan diharapkan dapat meningkatkan kemampuan daerah tersebut dalam pembiayaan pembangunan daerah serta pelayanan publik atas landasan kebutuhan dan memperkecil ketergantungan pemerintah daerah kepada pemerintah pusat. Pemerintah daerah mampu melaksanakan otonomi daerah didasari akan dua hal. Pertama, pemerintah daerah mampu 
mengoptimalkan kemampuan - kemampuan yang dimiliki, dan mampu mengelola keuangan tersebut untuk penyelenggaraan pemerintahan tersebut. Kedua, pemerintah daerah mampu meminimalisir ketergantungan kepada pemerintah pusat agar Pendapatan Asli Daerah menjadi sumber atas keuangan.

Halim (2009, dalam Rahmawati, 2010) pemerintah daerah menghadapi permasalahan yang kaitan dalam penggalian sumber pajak serta restribusi daerah yang merupakan salah satu komponen atas Pendapatan Asli Daerah yang belum memberikan kontribusi secara komplek terhadap penerimaan daerah secara keseluruhan, hal ini akan menjadikan kebocoran yang memberikan dampak besar diantara $10 \%$ hingga $50 \%$.

\section{Belanja Daerah}

Belanja diketahui sebagai pengeluaran dari atas dana pemerintah daerah yang mengurangi saldo anggaran lebih dalam periode tahun anggaran berjalan dimana tidak akan diperoleh pembayarannya kembali oleh pemerintah (PP No. 71 Tahun 2010). Sedangkan Belanja Daerah menurut UU No. 33 tahun 2004 adalah semua kewajiban daerah yang diakui sebagai pengurang nilai kekayaan bersih dalam periode tahun anggaran yang bersangkutan. Belanja dalam laporan keuangan menjadi salah satu pos yang terdapat dalam Laporan Realisasi Anggaran, dimana penyusunan Laporan Realisasi Anggaran ini masih menggunakan basis kas. Berdasrakan Pasal 36 Permedagri No. 13/2006, Belanja diklasifikasikan berdasarkan jenis belanja sebagai berikut belanja tidak langsung dan belanja langsung. Disaat pemerintah daerah dalam melaksanakan kegiatan dan program apabila tidak terkait secara langsung akan diklasifikasi sebagai belanja tidak langsung. Sedangkan untuk kegiatan dan program pemerintah saat anggaran terkait secara langsung maka akan dikategorikan sebagai belanja langsung.

Penggunaan sumberdaya dalam rangka pelaksanaan urusan pemerintahan menjadi kewenangan provinsi atau kabupaten/kota yang terdiri dari urusan wajib dan urusan pilihan. Saat pemerintah daerah dalam melakukan urusan wajib akan diprioritaskan untuk melindungi dan meningkatkan kualitas kehidupan masyarakat dalam upaya memenuhi kewajiban daerah yang diwujudkan dalam meningkatkan pelayanan dasara, pendidikan, kesehatan, fasilitas social dan fasilitas umum yang layak serta mengambangkan sistem jaminan sosial. Dalam alokasi sumber daya belanja akan menjadi proses yang tidak bisa ditebak. Sumber daya yang terbatas dan kebutuhan yang tidak ada batasnya menciptakan persaingan antara instansi pemerintahan. Berbagai strategi dilakukan untuk bisa mendapatkan jumlah alokasi sumberdaya yang sesuai dengan keinginan budget actors.

\section{Budget Ratcheting}

Pencapaian atas target dan capaian kinerja tahun lalu menjadi informasi yang digunakan dalam penentuan target di tahun masa depan. Abdullah dan Junita, (2016) menyatakan bahwa dalam penelitiannya saat pemerintah daerah menjadikan informasi tahun lalu yang bersifat menguntungkan dimana menjadi dasar atas penentuan anggaran di tahun berikutnya disebut budget ratcheting. Lim (2011) melakukan penelitian yang menyatakan bahwa varian saat pendapatan positif akan berhubungan dengan anggaran pendapatan pada masa depan, lalu varian pendatapan secara negatif tidak akan berhubungan dengan anggaran pendapatan di tahun berikutnya. Varian positif yang terjadi di masa lalu menjadi cerminan atas kinerja yang baik, sehingga jalan yang telah di tempuh di masa lalu menjadi pedoman atas masa depan. Pemerintah daerah pada pelaksanaanya terjadi agency problem yang kompleks yang berbanding lurus dengan asimetri informasi, sehingga kemungkinan terjadinya Budget Ratcheting juga semakin besar. 
Pendapatan yang berasal dari pajak mengalami kenaikan, maka hal tersebut juga berdampak pada peningkatan pembiayaan pemerintah. Pembiayaan pemerintah tersebut tidak akan kembali turun, meskipun terjadi penolakan terhadap naiknya pajak ataupun pajak tersebut diturunkan kembali. Model persamaan dari Ratchet memprediksi bahwa target pengeluaran akan relatif konstan, kecuali terdapat gangguan dari beberapa peristiwa eksternal (Aranda, 2010). Budget Ratcheting mengakibatkan anggaran pada masa yang akan datang akan sama dengan anggaran periode sebelumnya ditambah anggaran pada sektor pemerintah memiliki perbedaan dengan anggaran pada perusahaan diantaranya: Pertama, penganggaran pada pemerintah disusun dengan tujuan menganggarkan belanja atau pembiayaan untuk pembangunan daerah tersebut dan melakukan operasional pemerintahan, sedangkan pada perusahaan penganggaran dilakukan untuk menganggarkan laba. Kedua, Budget Ratcheting pada anggaran perusahaan terkait dengan bonus yang didapatkan berdasarkan pencapaian laba yang memberi manfaat bagi perusahaan, sedangkan Budget Ratcheting pada pemerintah terkait dengan kerugian pada masyarakat akibat pertumbuhan anggaran yang tidak efisien (Lee \& Plummer, 2007).

\section{Pengembangan Hipotesis}

\section{Pengaruh Pendapatan Asli Daerah terhadap Belanja Daerah}

Saat anggaran yang disusun memberikan dampat defisit atas realisasinya, hal ini menandakan tingginya persaingan dalam pengalokasian atas sumberdaya pada anggaran pemerintahan daerah. Abdullah, (2012) saat penganggaran di sektor publik akan diikuti agency problem dikarenakan kepentingan konstituen dan anggota terpilih dan perilaku opurtunistik budget actors. DPRD memiliki kecendrungan perilaku opurtunistik dalam mengusulkan anggaran menjadikan penerimaan daerah dari pendapatan asli daerah yang kemudian digunakan dalam menjalankan alokasi belanja yang telah diusulkan dalam pembahasan dalam rancangan Perda APBD. Dimana dalam perubahan kenaikan alokasi belanja yang diajukan DPRD mengandung masalah keagenan yang akan memberikan manfaat dalam memenuhi self interest dewan perwakilan.

Rahmawati (2010) mengemukakan hasil penelitian bahwa pendapatan asli daerah berpengaruh positif terhadap alokasi belanja daerah. Pemerintah daerah yang memiliki pendapatan asli daerah yang tinggi maka pengeluaran untuk alokasi belanja daerahnya juga semakin tinggi. Semakin besar dana yang diterima melalui pendapatan asli daerah maka akan semakin besar pula dana yang harus dialokasikan dalam Belanja Daerah. Penelitian lainnya menemukan bahwa pendapatan asli daerah berpengaruh positif terhadap belanja daerah. Semakin tinggi pendapatan daerah yang bersumber dari Pendapatan Asli Daerah maka akan semakin tinggi pula belanja daerah (Hamdani, dkk, 2015).

H1: Pendapatan Asli Daerah berpengaruh terhadap Belanja Daerah

\section{Pengaruh Budget Ratcheting Terhadap Hubungan Antara Pendapatan Asli Daerah Dengan Belanja Daerah}

Abdullah dan Afrah, (2016) saat penggunaan informasi tahun sebelumnya digunakan yang bersifat menguntungkan sehingga dijadikan dasar atas acuan dalam penentuan target tahun berikutnya disebut budget ratcheting. Menurut Lim (2011) varian positif menunjukkan kinerja yang dilakukan telah baik. Varian atas pendapatan yang memliki informasi positif akan berasosiasi dengan anggaran pendapatan pada masa yang akan datang, dibandingkan varian pendapatan yang negatif tidak berhubungan dengan anggaran pendapatan pada masa depan. Lalu dijadikan sebagai acuan untuk penentuan target kinerja pada tahun berikutnya. Budget ratcheting, dalam segi konsep 
keagenan akan bermakna asimetri informasi tinggi maka kemungkinan terjadinya budget ratcheting akan semakin besar.

Lee dan Plummer, (2007) menyatakan bahwa politik ekonomi yang dilakukan penguasa, diamana aktualnya terjadi pemaksimalan anggaran dengan memanfaatkan kekuasaan yang dimiliki. Kim (2002) menyatakan apabila agency problem semakin besar dalam pemerintahan daerah akan berbanging lurus dengan Budget Ratcheting, lalu akan diikuti dengan terjadinya varian negatif yang terjadi lemahnya kekuasaan atas kepala daerah tersebut. Begitupun juga saat adanya varian positif akan semakin kuat dikarenakan kuatnya kekuasaan kepala daerah. Agency problem menjadi semakin besar lalu memberikan dampak atas target anggaran pendapatan periode masa depan kurang responsif terhadap varians saat ini.

H2: Budget Ratcheting berpengaruh terhadap hubungan antara Pendapatan Asli Daerah dengan Belanja Daerah.

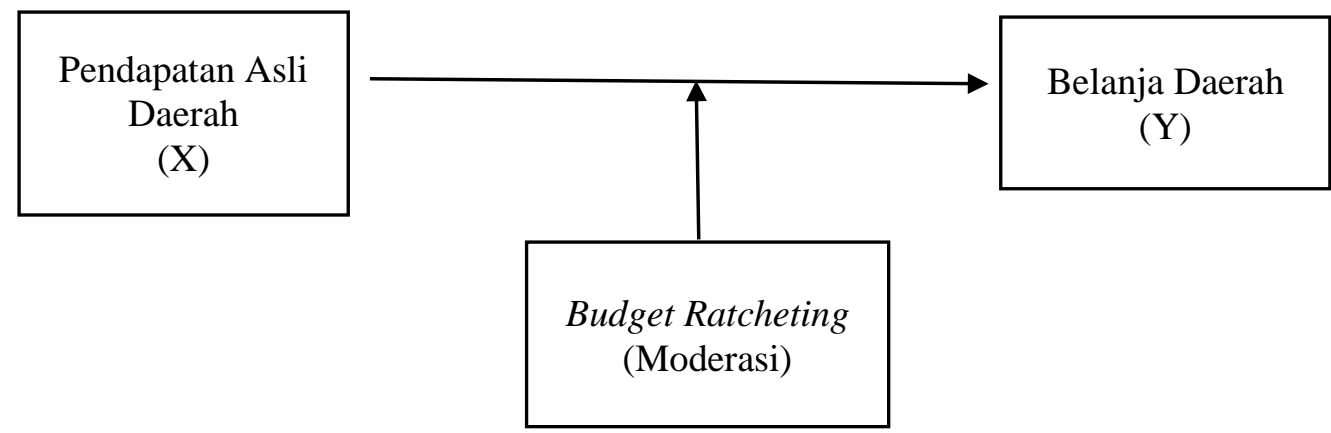

Gambar 1. Kerangka Konseptual

\section{METODE PENELITIAN}

\section{Data dan Sampel}

Penelitian yang dilakukan menggunakan data sekunder yang bersumber dari Laporan Keuangan Pemerintah Daerah Kabupaten/Kota tahun 2013 - 2017. Sampel final pada penelitian ini didasari berdasarkan metode purposive sampling, maksudnya pengambilan sampel dilakukan dengan melihat beberapa kriteria, antara lain : 1. Pemerintah Daerah yang menerima dana otonomi khusus, 2. Data tersedia lengkap untuk Laporan Keuangan selama 5 tahun anggaran tahun 2013 sampai dengan tahun 2017. 3. Daerah tersebut tidak daerah pemekaran baru atau paling lambat sudah berdiri selama 5 tahun. Atas kriteria tersebut, diperoleh sampel sebanyak 19 buah yang terdiri dari Kabupaten/Kota di Provinsi Sumatera Barat.

\section{Operasional Variabel Penelitian}

Penelitian yang dilakukan dengan menggunakan 3 variabel. Pendapatan Asli Daerah digunakan sebagai Variabel Independen (X). Belanja Daerah digunakan sebagai Variabel Dependen (Y). Selanjutnya Budget Ratcheting digunakan sebagai Variabel Moderasi. Definisi dan pengukuran masing - masing variabel tersebut adalah:

a. Belanja Daerah.

Belanja Daerah menjadi sumber pengurangan nilai kekakyaan bersih dalam satu tahun anggaran, dimana merupakan sumber daya yang digunakan dalam melaksanakan fungsi - fungsi pemerintahan daerah. Belanja Daerah dalam penelitian ini diukur dengan menggunakan skala 
nominal dengan satuan Rupiah dan dapat diketahui dari Laporan Realisasi Anggaran Pemerintah Daerah Kabupaten/Kota di Provinsi Sumatera Barat dari tahun 2013 - 2017.

b. Pendapatan Asli Daerah

Pendapatan Asli Daerah merupakan asal atas potensi yang dimiliki suatu pemerintah daearah. Pendapatan Asli Daerah dalam penelitian ini diukur dengan menggunakan skala nominal dengan satuan Rupiah dan dapat diketahui dari Laporan Realisasi Anggaran Pemerintah Daerah Kabupaten/Kota di Provinsi Sumatera Barat dari tahun 2013 - 2017.

\section{c. Budget Ratcheting}

Variabel moderasi adalah variabel yang mempengaruhi (memperkuat atau memperlemah) hubungan antara variabel bebas dan terikat. Dimana variabel moderasi pada penelitian ini adalah Budget Ratcheting.Pengukuran pada variabel ini menggunakan moder dari Aranda (2010) dalam Abdullah \& Junita (2016) dengan rumus sebagai berikut:

$$
P A D_{t}-P A D_{t-1}=\delta+\gamma\left(P A D R_{t-1}-P A D_{t-1}\right)+\varepsilon
$$

Dimana PADt menjelaskan sebagai anggaran Pendapatan Asli Daerah pada tahun t, PADt-1 sebagai anggaran PAD pada tahun t-1, $\boldsymbol{\delta}$ sebagai konstanta, $\boldsymbol{\gamma}$ sebagai koefisien regresi, PADRt-1 sebagai realisasi PAD tahun t-1, dan $\boldsymbol{\varepsilon}$ sebagai error terms. PADt - PADt-1, digunakan untuk mengukur kenaikan anggaran PAD tahun berjalan dibandingkan dengan anggaran PAD tahun lalu, sebagai cerminan adanya Budget Ratcheting dalam penentuan target PAD.

\section{Metode Analisis}

Analisis regresi dengan variabel moderasi merupakan analisis regresi yang melibatkan variabel moderasi dalam membangun model hubungannya. Variabel moderasi berperan sebagai variabel yang dapat memperkuat atau memperlemah hubungan antara variabel dependen dengan variabel independen. Model persamaan atas pengujian analisi regresi moderasi pada penelitian ini adalah sebagai berikut:

$$
\begin{array}{ll}
B D=a+b_{1} P A D+e & \text { Persamaan I } \\
B D=a+b_{1} P A D+b_{2} B R+b_{3} P A D \times B R+e & \text { Persamaan II }
\end{array}
$$

BD sebagai Belanja Daerah ditunjuk menjadi Variabel Dependen, PAD sebagai pendapatan asli daerah ditunjuk menjadi variabel independen, lalu BR sebagai Budget Ratcheting ditunjuk sebagai variabel moderasi.

\section{HASIL DAN PEMBAHASAN}

\section{Statistik Deskriptif}

Statistik deskriptif penelitian dapat dilihat pada tabel di bawah ini 


\section{Tabel 1 \\ Hasil Uji Statistik Deskriptif}

\begin{tabular}{lccccc} 
Descriptive Statistics & \multicolumn{1}{l}{} \\
\hline Pendapatan Asli Daerah & 94 & 10,3 & 11,7 & 10,824 &, 2758 \\
Belanja Daerah & 94 & 11,3 & 12,2 & 11,670 &, 2332 \\
Budget Ratcheting & 94 & 1,5 & 3,9 & 2,287 &, 2146 \\
Valid N (listwise) & 94 & & & & \\
\hline Sumber : Data Sekunder diolah melalui SPSS, 2019 & &
\end{tabular}

Hasil dari tabel 1 (uji statistik deskriptif) menunjukkan Variabel PAD memiliki rentang nilai dari 10,3 sampai dengan 11,7. Nilai rata - rata PAD adalah 10,824 dan memiliki standar deviasi sebesar 0,2758. Sedangkan variabel Belanja Daerah memiliki rentang nilai 11,3 sampai dengan 12,2, dimana nilai rata - rata Belanja Daerah adalah 11,670 dan memiliki standar deviasi sebesar 0,2332. Variabel Budget Ratcheting yang dihitung menggunakan model Aranda (2010) dalam Abdullah \& Junita (2016) memiliki rentang nilai 1,5 sampai dengan 3,9. Dimana rata - rata dari Budget Ratcheting adalah 2,287 dan memiliki standar deviasi sebesar 0,2146.

\section{Uji Normalitas}

\section{Tabel 2}

Hasil Uji Normalitas One-Sample Kolmogorov-Smirnov Test

\begin{tabular}{llr} 
& & Unstandardized Residual \\
\hline $\mathrm{N}$ & & 94 \\
\hline Normal Parameters & Mean & .0000000 \\
& Std. Deviation & .18337714 \\
Most Extreme Differences & Absolute & .077 \\
& Positive & .077 \\
& Negative & -.072 \\
Test Statistic & .077 \\
Asymp. Sig. (2-tailed) & $.200^{\mathrm{c}, \mathrm{d}}$ \\
\hline a. Test distribution is Normal. \\
b. Calculated from data. \\
c. Lilliefors Significance Correction. \\
d. This is a lower bound of the true significance. \\
Sumber : Data Sekunder diolah melalui SPSS, 2019
\end{tabular}

Hasil dari tabel diatas memperlihatkan hasil atas Asymp. Sig (2-tailed) sebesar 0,2 yang artinya $>0,05$, maka dari hasil tersebut dapat disimpulkan tingkat signifikansi pada atas variabel penelitian ini berdistribusi secara normal. Dengan demikian, residual data berdistribusi secara normal dan model regresi telah memenuhi asumsi normalitas. 


\section{Uji Multikoliniearitas}

Tabel 3

\section{Hasil Uji Multikoliniearitas}

\begin{tabular}{lrl}
\hline \multirow{2}{*}{ Coefficients $^{\mathbf{a}}$} & & \\
\cline { 2 - 3 } Model & \multicolumn{2}{c}{ Collinearity Statistics } \\
\cline { 2 - 3 } Pendapatan Asli Daerah &, 967 & 1,034 \\
Budget Ratcheting &, 967 & 1,034 \\
\hline
\end{tabular}

a. Dependent Variable: Belanja Daerah

Sumber : Data Sekunder diolah melalui SPSS, 2019

Berdasarkan tabel 3 diatas dapat dilihat hasil perhitungan nilai VIF untuk Pendapatan Asli Daerah sebesar 1,034 dengan Tolerance sebesar 0,967, dan nilai VIF Budget Ratcheting sebesar 1,034 dengan Tolerance sebesar 0,967. Semua variabel memenuhi syarat bebas multikolinieritas yaitu nilai Tolerance $>0,1$ dan niali VIF $<10$. Sehingga dapat disimpulkan bahwa tidak terdapat gejala multikolinieritas antar variabel independen untuk persamaan regresi.

\section{Uji Heterokedastisitas}

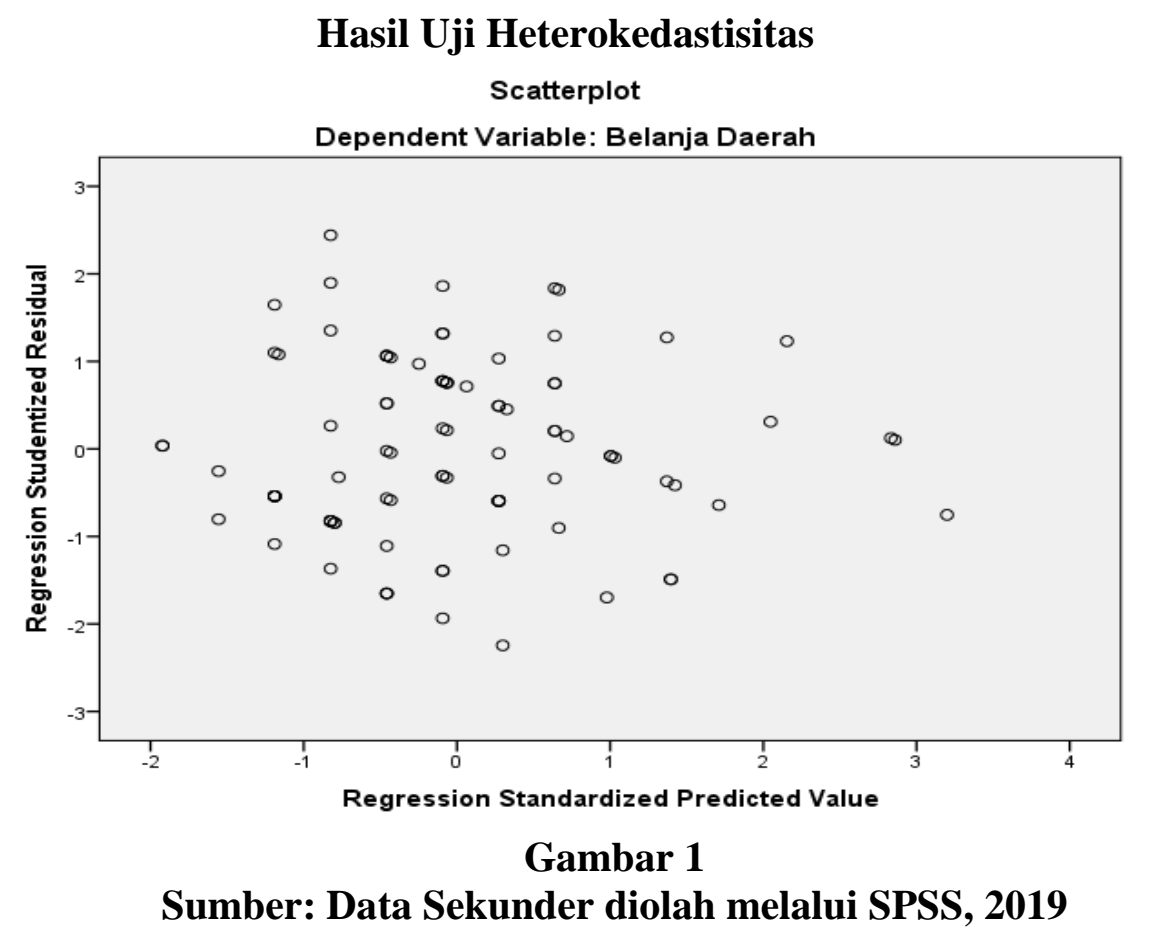

Berdasarkan gambar 1 bahwa dapat dilihat hasil uji heterokedastisitas dengan scatter plot bisa dilihat dari pola titik menyebar secara acak serta tersebar baik diatas maupun di bawah angka 0 dan sumbu Y, sehingga disimpulkan bahwa tidak terjadi heterokedastisitas. 


\section{Uji Autokorelasi}

\section{Tabel 4 \\ Hasil Uji Autokorelasi}

\begin{tabular}{l} 
Model Summary \\
\begin{tabular}{l} 
Model Durbin-Watson \\
\hline 1
\end{tabular} \\
\hline a. Predictors: (Constant), Budget Ratcheting, Pendapatan Asli Daerah \\
b. Dependent Variable: Belanja Daerah \\
Sumber : Data Sekunder diolah melalui SPSS, 2019
\end{tabular}

Dari tabel di atas dapat dilihat bahwa nilai Durbin-Watson (DW) adalah sebesar 0,749 yang berarti berada diantara -2 sampai +2 , sehingga dapat disimpulkan bahwa tidak terdapat autokorelasi atau tidak ada korelasi antar data berdasarkan urutan waktu dan model regresi untuk penelitian ini dapat diterima.

\section{Analisis Regresi}

Tabel 5

\section{Hasil Estimasi Analisis Regresi Sederhana}

\section{Coefficients $^{\mathrm{a}}$}

\begin{tabular}{|c|c|c|c|}
\hline \multirow[b]{2}{*}{ Model } & \multicolumn{2}{|c|}{ Unstandardized Coefficients } & \multirow{2}{*}{$\frac{\text { Standardized Coefficients }}{\text { Beta }}$} \\
\hline & $\mathrm{B}$ & Std. Error & \\
\hline $\begin{array}{ll}1 & \text { (Constant) }\end{array}$ & 6,026 & ,751 & \\
\hline Pendapatan Asli Daerah &, 521 & ,069 & ,617 \\
\hline
\end{tabular}

a. Dependent Variable: Belanja Daerah

Sumber : Data Sekunder diolah melalui SPSS, 2019

Dari hasil tersebut apabila ditulis dalam persamaan regresi sederhana adalah sebagai berikut :

$$
\begin{gathered}
B D=a+b_{1} P A D+e \\
B D=6,026+0,521 \text { PAD }
\end{gathered}
$$

Dilihat tabel diatas nilai koefisien konstanta adalah 6,026, dan nilai koefisien regresi Pendapatan Asli Daerah sebesar 0,521 yang menunjukkan bahwa PAD mempunyai pengaruh positif sebesar 0,521 terhadap Belanja Daerah, artinya semakin meningkat Pendapatan Asli Daerah maka juga akan meningkatkan Belanja Daerah pada Pemerintah Daerah tersebut. 
Tabel 6

Hasil Estimasi Moderating Regression Analysis

\begin{tabular}{|c|c|c|c|}
\hline \multicolumn{4}{|l|}{ Coefficients $^{\mathbf{a}}$} \\
\hline \multirow[t]{2}{*}{ Model } & \multicolumn{2}{|c|}{ Unstandardized Coefficients } & $\begin{array}{l}\text { Standardized } \\
\text { Coefficients }\end{array}$ \\
\hline & $\mathrm{B}$ & Std. Error & Beta \\
\hline \multirow{4}{*}{$\begin{array}{ll}1 & \text { (Constant) } \\
& \text { Pendapatan Asli Daerah } \\
& \text { Budget Ratcheting } \\
& \text { PAD X BR } \\
\end{array}$} & 6,000 & 1,710 & \\
\hline &, 532 & ,158 & ,629 \\
\hline &,- 016 & ,613 &,- 015 \\
\hline &,- 002 &, 056 &,- 022 \\
\hline
\end{tabular}

a. Dependent Variable: Belanja Daerah

Sumber: Data Sekunder diolah melalui SPSS, 2019

Dari hasil tersebut apabila ditulis dalam bentuk dari persamaan regresinya adalah sebagai berikut

$$
\begin{gathered}
B D=a+b_{1} P A D+b_{2} B R+b_{3} P A D \times B R+e \\
B D=6,000+0,532 P A D-0,016 B R-0,002 P A D \times B R+e
\end{gathered}
$$

Dari hasil tabel diatas menunjukkan nilai konstanta sebesar 6,000, dan nilai koefisien regresi Pendapatan Asli Daerah mempunyai pengaruh positif sebesar 0,532 terhadap Belanja Daerah, artinya semakin meningkat PAD maka akan meningkatkan juga terhadap Belanja Daerah. Sedangkan jika ditambahkan budget ratcheting sebagai variabel moderasi maka menghasilkan nilai koefisien sebesar 0,002 terhadap Belanja Daerah.

\section{Uji Koefisien Determinasi}

\section{Tabel 7}

\section{Hasil Uji Koefeisien Determinasi Pendapatan Asli Daerah terhadap Belanja Daerah}

Model Summary

\begin{tabular}{llllll}
\hline Model & R & R Square & Adjusted R Square & Std. Error of the Estimate \\
\hline 1 & $.617^{\text {a }}$ & .380 & .374 & .1845 \\
\hline
\end{tabular}

a. Predictors: (Constant), Pendapatan Asli Daerah

Sumber: Data Sekunder diolah melalui SPSS, 2019

Tabel 8

Hasil Uji Koefeisien Determinasi Pendapatan Asli Daerah, Budget Ratcheting, dan Pendapatan Asli Daerah X Budget Ratcheting terhadap Belanja Daerah

Model Summary

\begin{tabular}{lrrrr}
\hline Model & R & R Square & Adjusted R Square & Std. Error of the Estimate \\
\hline 1 & $.618^{\mathrm{a}}$ & .382 & .361 & .1864 \\
\hline
\end{tabular}

a. Predictors: (Constant), PAD X BR, Pendapatan Asli Daerah, Budget Ratcheting

Sumber: Data Sekunder diolah melalui SPSS, 2019

Hasil tabel 7 menunjukkan nilai Adjusted $R$ Square sebesar 0,370, hal ini dapat disimpulkan bahwa kemampuan variabel bebas dalam menjelaskan varians dari variabel terikatnya adalah sebesar 37\%, berpengaruh terhadap Pendapatan Asli Daerah sedangkan sisanya sebesar 63\% dijelaskan oleh variabel atau faktor lain. Pada tabel 8 menunjukkan Adjusted $R$ Square mengalami 
penurunan menjadi 0,361, dan dari hasil tersebut diketahui bahwa 36,1\% Belanja Daerah dapat dijelaskan oleh Pendapatan Asli Daerah dan Budget Ratcheting sebagai variabel moderasi memperlemah dalam memoderasi Pendapatan Asli Daerah terhadap Belanja Daerah.

Uji F

ANOVA $^{\mathrm{a}}$

Tabel 9

Hasil Uji F

\begin{tabular}{lccccc}
\hline Model & Sum of Squares & df & Mean Square & F & Sig. \\
\hline $1 \quad$ Regression & 1.929 & 3 & .643 & 18.508 & $.000^{\mathrm{b}}$ \\
Residual & 3.127 & 90 & .035 & & \\
\multicolumn{1}{c}{ Total } & 5.057 & 93 & & & \\
\hline
\end{tabular}

a. Dependent Variable: Belanja Daerah

b. Predictors: (Constant), PAD X BR, Pendapatan Asli Daerah, Budget Ratcheting

Sumber: Data Sekunder diolah melalui SPSS, 2019

Dari hasil tabel diatas diketahui bahwa Fhitung sebesar 18,508 dengan probabilitas sebesar 0,00. Diketahui bahwa Ftabel sebesar 3,10 < dari Fhitung, dan angka probabilitas tersebut lebih kecil dari nilai 0,05. Dengan demikian, dapat disimpulkan bahwa model yang digunakan untuk menguji PAD adalah model yang fit. Persaman regresi dapat dinyatakan signifikan yang berarti bahwa PAD dan Budget Ratcheting berpengaruh signifikan terhadap Belanja Daerah.

Uji t

Tabel 10

Coefficients $^{\mathbf{a}}$

\section{Hasil Uji Statistik t}

\begin{tabular}{lccccc}
\hline \multirow{2}{*}{ Model } & \multicolumn{2}{c}{$\begin{array}{c}\text { Unstandardized } \\
\text { Coefficients }\end{array}$} & $\begin{array}{c}\text { Standardized } \\
\text { Coefficients }\end{array}$ & \multirow{2}{*}{ T } & \multirow{2}{*}{ Sig. } \\
\cline { 2 - 4 } & $\mathrm{B}$ & Std. Error & Beta & & \\
\hline (Constant) & 6.000 & 1.710 & & 3.508 & .001 \\
1 Pendapatan Asli Daerah & .532 & .158 & .629 & 3.376 & .001 \\
Budget Ratcheting & -.016 & .613 & -.015 & -.027 & .979 \\
PAD X BR & -.002 & .056 & -.022 & -.035 & .972 \\
\hline
\end{tabular}

a. Dependent Variable: Belanja Daerah

Sumber: Data Sekunder diolah melalui SPSS, 2019

Dari perhitungan yang telah dilakukan diperoleh ttabel sebesar 1,661 dengan taraf signifikasi 0,05. Diketahui untuk Pendapatan Asli Daerah diperoleh nilai thitung $>$ ttabel yaitu 3,376 >1,661. Nilai signifikansi (sig) 0,001 < 0,05 maka disimpulkan bahwa hipotesis pertama diterima yang artinya Pendapatan Asli Daerah memiliki pengaruh signifikan terhadap Belanja Daerah. Sedangkan untuk Budget Ratcheting dan PAD x Budget Ratcheting memperoleh nilai thitung < tabel yaitu -0,027, $0,035<1,661$. Nilai Signifikansi (sig) Budget Ratcheting dan Pendapatan Asli Daerah x Budget Ratcheting yaitu 0,979, 0,972>0,05.

\section{PEMBAHASAN}

\section{Pengaruh Pendapatan Asli Daerah terhadap Belanja Daerah}

Hasil uji regresi secara parsial menunjukkan tingkat sig yang diperoleh sebesar 0,001 lebih kecil dari 0,05, maka dapat dimaknai bahwa Pendapatan Asli Daerah berpengaruh terhadap Belanja Daerah, dan nilai koefisien regresi sebesar 0,532 yang memiliki arah positif. Hasil ini 
sejalan dengan penelitian yang dilakukan Wati (2017) yang hasil Uji statistik menunjukkan PAD memiliki pengaruh sebesar 0,694 dengan arah positif terhadap Belanja Daerah, yang artinya ketika PAD mengalami peningkatan, maka Belanja Daerah juga akan mengalami peningkatan. Penelitian yang dilakukan Ernayani (2017) berdasarkan hasil uji t variabel PAD berpengaruh signifikan terhadap Bealnja Daerah.

Beberapa hasil penelitian sebelumnya menunjukkan bahwa PAD merupakan sumber pendapatan yang menjadi poin penting bagi sebuah daerah dalam memenuhi belanjanya. PAD juga menujukkan tingkat kemandirian suatu daerah. Semakin tinggi PAD yang diperoleh suatu daerah maka akan semakin tinggi kemungkinan daerah tersebut untuk memnuhi kebutuhan Belanja Daerahnya sendiri tanpa harus tergantung kepada Pemerintah Pusat.

\section{Pengaruh Budget Ratcheting terhadap Hubungan antara Pendapatan Asli Daerah dengan Belanja Daerah}

Peneliti menentukan hipotesis kedua bahwa adanya pengaruh Budget Ratcheting sebagai moderasi dalam hubungan antara PAD dengan Belanja Daerah. Hasil uji pada tabel regresi yang pertama menunjukkan nilai Adjusted $R$ Square sebesar 0,374 dan setelah ada persamaan regresi kedua (MRA) nilai Adjusted $R$ Square turun menjadi 0,361. Maka dari hasil tersebut dapat diketahui bahwa hubungan PAD dengan Belanja Daerah diperlemah oleh Budget Ratcheting. Berbeda dengan hasil penelitian Nurhayati (2018) memberikan hasil pada regresi pertama sebesar 0,341. Angka $R$ Square mengalami peningkatan setelah ada persamaan regresi kedua menjadi 0,358. Maka dengan melihat hasil tersebut menyatakan bahwa pada Budget Ratcheting memperkuat hubungan antara PAD dengan Belanja Daerah.

Penelitian Susanto (2018) mendapatkan hasil penelitian bahwa koefisien varian positif anggaran PAD bernilali signifikan pada tingkat signifikansi 1\%. Namun, koefisien varian negatif anggaran PAD tidak bernilai signifikan. Temuan tersebut mendukung hipotesis yaitu terjadi efek ratchet dalam penganggaran pendapatan asli daerah. Abdullah \& Junita (2016) mendapatkan hasil penelitian bahwa koefisien regresi pada variabel moderasi adalah 0,0000002491 dan signifikansi pada level a=5\%, yang berarti budget ratcheting mempunyai efek moderasi dan terdapat hubungan antara Pendapatan Asli Daerah dan Belanja Daerah. Dari dua hasil uji regresi yang dilakukan memperoleh hasil terjadi kenaikan $R$ Square dari 0,847 menjadi 0,939, dimana hal ini menunjukkan bahwa Budget Ratcheting dapat memoderasi hubungan antara Pendapatan Asli Daerah dan Belanja Daerah.

Penerapan anggaran yang ketika penyusun anggaran dan pemberi persetujuan memiliki kepentingan masing - masing, hal ini akan menunjukkan terjadinya slack dalam proses penentuan target kerja. Susanto (2018) menyebutkan perbedaan respon terhadap varian anggaran yang positif juga menjadi hal yang patut diperhatikan, literature menyebutkan bahwa perbedaan respon tersebut sebagai asymmetric ratchet karena penyusunan PAD pada penyusunan anggaran memberikan perhatian lebih besar pada varian positif.

\section{SIMPULAN, KETERBATASAN DAN SARAN Simpulan}

Penelitian ini bertujuan untuk menemukan bukti empiris pengaruh PAD terhadap Belanja Daerah dan Budget Ratcheting sebagai variabel moderasi di Pemerintah Daerah Kabupaten/Kota Provinsi Sumatera Barat pada tahun 2013 - 2017. Berdasarkan hasil pengujian statistik yang telah dilakukan, maka dapat disimpulkan sebagai berikut: 
1. Hasil penelitian ini menunjukan nilai t hitung sebesar 3,376 > 1,661 dan sig 0,001 $<0,005$, sehingga memberikan hasil bahwa Pendapatan Asli Daerah berpengaruh terhadap Belanja Daerah, dan hal ini mendukung hipotesis yang dirumuskan. Dimana hal ini juga menunjukkan hubungan positif, ketika Pendapatan Asli Daerah mengalami pengingkatan, maka juga akan berdampakan kenaikan pada Belanja Daerah.

2. Budget Ratcheting merupakan variabel moderasi yang memperlemah terhadap hubungan Pendapatan Asli Daerah dengan Belanja Daerah. Hasil penelitian menunjukkan Adjusted $R$ Square 0,374 atau 37,4\% pada regresi pertama dan Adjusted $R$ Square mengalami penurunan setelah regresi kedua (MRA) menjadi 0,361 atau 36,1\%. Sehingga dapat disimpulkan bahwa Budget Ratcheting memperlemah dalam hubungan Pendapatan Asli Daerah dengan Belanja Daerah.

\section{Keterbatasan}

Meskipun peneliti telah berusaha merancang dan mengembangkan penelitian sedemikian rupa, namun masih terdapat beberapa keterbatasan dalam penelitian yaitu :

1. Peneliti hanya meneliti secara umum untuk pemerintahan daerah Kabupaten/Kota, sehingga untuk lebih memberikan hasil yang baik dilakukan penelitian SKPD pemerintah daerah tersebut.

2. Pengaruh dari variabel yang telah ditentukan peneliti memiliki tingkatan yang kecil sehingga hasil kurang memuaskan.

\section{Saran}

Berdasarkan pembahasan dan kesimpulan yang terdapat dalam penelitian ini, maka peneliti mengajukan beberap saran, sebagai berikut:

1. Menambah cakupan atas sampel yang akan akan dilakukan pada penelitian selanjutnya, seperti SKPD Pemerintah Daerah.

2. Memberikan variabel tambahan pada penelitian selanjutnya yang dianggap memiliki pengaruh terhadap Belanja Daerah, seperti luas wilayah, jumlah anggota parlemen, dan lain - lain.

3. Menjadikan Budget Ratcheting sebagai variabel terikat, sehingga kemungkinan untuk memberikan hasil yang berbeda.

\section{DAFTAR PUSTAKA}

Abdullah, Syukriy \& Ramadhaniatun Nazry. (2014). Analisis Varian Anggaran Pemerintah Daerah: Penjelasan Empiris dari Perspektif Keagenan. Jurnal Samudra Ekonomi dan Bisnis, 6(2): 72-283.

Abdullah, Syukriy \& Afrah Junita. (2016). Bukti Empiris tentang Pengaruh Budget Ratcheting terhadap Hubungan antara Pendapatan Sendiri dan Belanja Daerah Pada Kabupaten/Kota di Aceh. Jurnal Modus, 28(2): 185-202.

Aranda, Carmen dkk. (2010). Ratcheting Effect and The Role of Relative Target Setting.

Bawono, I. R., Halim, A \& Lord, B. (2012). Public sector performance measurement and budget allocation: An Indonesian experiment. artikel dipresentasikan di the 6th NZ Management Accounting Conference, New Zealand.

Bouwens, Jan \& Peter Kroos. (2010). Target Ratcheting and Effort Reduction. Journal of Accounting and Economics, 51(1-2): 171-185. 
Fozzard, Adrian. (2001). The basic budgeting problem: Approaches to resource allocation in the public sector and their implications for pro-poor budgeting. Working paper 147. Center for Aid and Public Expenditure, Overseas Development Institute (ODI).

Halim, Abdul. \& Abdullah, S. (2010). Hubungan dan masalah keagenan di pemerintah daerah. Jurnal Akuntansi Pemerintah, 2(1), 53-64.

Halim, Abdul \& Muhammad Syam Kusufi. (2012). Akuntansi Sektor Publik Akuntansi Keuangan Daerah. Jakarta: Salemba Empat.

Halim, Abdul. (2002). Analisis varian pendapatan asli daerah dalam laporan perhitungan anggaran pendapatan dan belanja daerah kabupaten/kota di Indonesia. Disertasi. Universitas Gadjah Mada.

Hercowitz, Zhi \& Strawczynski. (2004). Cyclical Ratcheting In Government Spending: Evidence From The OECD. The Review of Economics and Statistics, 86(1): 353-361.

Isaksen. Jan. 2005. The Budget Process and Corruption. U4 - Anti Corruption Resource Centre.

Jensen, Michael C. \& Meckling, William H. (1976). Theory of The Firm: Managerial Behavior, Agency Costs and Ownership Structure. Juornal of Financial Economics, 3: 305-360.

Jogiyanto H.M. (2004). Metodologi Penelitian Bisnis: Salah Kaprah dan Pengalamanpengalaman.Yogyakarta: BPFE.

Lee, Tanya M. \& Elizabeth Plummer. (2007). Budget Adjustments in Response to Spending Variances: Evidence of Ratcheting of Local Government Expenditures. Journal of Management Accounting Research, 19: 137-167.

Leone, A. \& S. Rock. (2002). Empirical Tests of Budget Ratcheting and Its Effect on Managers' Discretionary Accrual Choices. Journal of Accounting and Economics, 33: 43-67.

LeLoup, Lance T. and William B. Moreland. (1978). Agency Strategies and Executive Review: The Hidden Politics of Budgeting. Public Administration Review, 38(3): 232-239.

Lim, Dongkuk. (2011). Budget Ratcheting and Agency problem. Dissertation. The University of Texas at Dallas.

Mardiasmo. (2006). Akuntansi Sektor Publik. Yogyakarta: Andi.

Marlowe, J. (2009). Budget variance, slack resources, and municipal expenditures. SSRN Library.

Nordiawan, Deddi \& Ayuningtyas Hertianti. (2010). Akuntansi Sektor Publik. Edisi 2. Jakarta: Salemba Empat.

Nurhayati, Neni. (2018). Pengaruh Budget Ratcheting Terhadap Hubungan Antara Pendapatan Asli Daerah dan Belanja Daerah Pada Kabupaten/Kota di Wilayah III Cirebon. Jurnal Riset Keuangan dan Akuntansi, 4(1): 29 - 32

Peraturan Menteri Dalam Negeri Nomor 21 Tahun 2011 tentang Pedoman Pengelolaan Keuangan Daerah.

Peraturan Pemerintah Nomor 71 Tahun 2010 tentang Standar Akuntansi Pemerintahan.

Peraturan Pemerintah Daerah Nomor 58 Tahun 2005 tentang Pengelolaan Keuangan Daerah.

Ritonga, I. T., C. Clark, \& G. Wickremasinghe. (2012). Assessing Financial Condition of Local Government in Indonesia: An Exploration. Public and Municipal Finance, 1(2).

Smith, Robert W. \& Mark Bertozzi. (1998). Principals and agents: An explanatory model of public budgeting. Journal of Public Budgeting, Accounting and Financial Management (Fall): 325353.

Susanto, Anindyo Aji \& Halim, Abdul. (2016). Efek Ratchet pada Anggaran Pemerintah Daerah: Studi pada Satuan Kerja Perangkat Daerah Pemerintah Provinsi Daerah Istimewa Yogyakarta. Jurnal Akuntansi \& Akuntabilitas Publik, 1(1): 88-96. 
Susanto, Anindyo Aji. (2018). Varian Anggaran Dan Peran Akuntansi Pertanggungjawaban Pada Penganggaran Pemerintah Daerah: Bukti Efek Ratchet Pada Anggaran Pemerintah Daerah (Studi Pada Satuan Kerja Perangkat Daerah Pemerintah Provinsi Daerah Istimewa Yogyakarta). Jurnal Ekonomi dan Bisnis, 1(2): 187-205.

Uma Sekaran. (2006). Metodologi Penelitian untuk Bisnis, Edisi 4, Buku 1, Jakarta: Salemba Empat.

Undang - Undang Nomor 23 Tahun 2014 tentang Pemerintah Daerah.

Undang - Undang Nomor 33 Tahun 2004 tentang Perimbangan Keuangan Antara Pemerintah Pusat dan Pemerintah Daerah.

Voorhees, W. (2006). Consistent Underestimation Bias, The Asymmetrical Loss Function, and Homogenous Sources of Bias In State Revenue Forecast. Journal of Public Budgeting, Accounting \& Financial Management, 18 (1), 61-76.

Weitzman, M. L. (1980). The Ratchet Principle and Performances Incentives. The Bell Journal of Economics, 11: 302-308. 